\title{
30 Years of Marine Educational Research in North America: A Review of Methodologies
}

\author{
Jong-Mun $\mathrm{KIM}^{+}$ \\ (The University of British Columbia) \\ 북미의 해양교육 연구 30년, 그 방법론에 대한 고찰 \\ 김 종 문 $^{+}$ \\ (브리티쉬 콜롬비아 대학교)
}

\section{국문초록}

인류의 해양에 대한 의존도가 점차 높아지면서 해양과 인류의 관계를 이해하고 이를 통해 해양의 지속가능성을 유지하기 위한 해양교육은 외국뿐만 아니라 국내에서도 더욱 활발하게 진행되어 가는 추세이다. 북미의 경우 해양교육의 증가에 비례하여 해양교육에 대한 연구도 양적으로 급격히 증가하 였음은 물론이고 그 방법 또한 매우 다양하게 이루어지고 있다. 연구란 연구자가 가진 패러다임, 존 재론, 인식론을 기반으로 이루어지므로 이에 대해 개략적으로 고찰한 뒤 양적, 질적, 혼합 방법론이 지닌 장점과 제한점을 논의한다. 해양교육과 관련된 북미의 연구논문들(1980년 2011년)을 대상으 로 연구자들이 사용한 다양한 연구방법 및 디자인을 연구사례와 함께 소개하여 한국에서의 해양교육 연구 설계를 위한 참고자료를 제공한다.

주제어 : 해양교육 연구, 방법론, 양적 연구, 질적 연구, 혼합방법 연구

\section{INTRODUCTION}

The oceans cover $71 \%$ of the earth's surface and are the most dominant feature of the Earth. They provide not only numerous habitats for marine organisms but also have a critical impact on human life in the domains of food, oxygen, climate control, source of fresh water, transportation, and development of history and culture (Mayer \& Fortner, 1985). Humans' heavy reliance on the ocean also means that humans significantly impact on the ocean. Confidence that the publics' understanding of the mutual influences shared by the ocean and humankind is integral to the Earth's sustainability (Cava, Schoedinger, Strang, \& Tddenham, 2005) justifies the need and importance of marine education.

In tandem with an increase in the development and implementation of both formal and informal marine educational programs, there has also been growth in educational research on marine education. Comprehensive reviews of marine educational research in North America reveal that there has been a surge in publications on the topic,

† Corresponding author : 1-604-822-2302, jongmunkim@gmail.com 
as well as a wider array of research methods and designs used to investigate it (Fortner, 1991, 2010).

In Korea, however, marine educational research is still in its early stages. Thus, the purpose of this paper is to introduce methods and designs common in the North American context, and to critically consider how these might be applied to further our understanding of marine education in Korea.

\section{PARADIGM, ONTOLOGY, EPISTEMOLOGY}

The purpose of a research is to increase our understanding of a phenomenon or issue and it begins with posing a research questions (Creswell, 2012). When a researcher conducts a research, it is built on the researcher's worldview, beliefs, and relationships with the phenomenon or issue. These are called paradigm, ontology, and epistemology. Maxwell (2005) explains that "paradigm is a set of very general philosophical assumptions about the nature of the world (ontology) and how we can understand it (epistemology)" (p. 36).

There are multiple but mainly two paradigms in the social science: positivism and constructivism Typically researchers who take the position that there is a real reality and that the relationship between the knower and the known is objective employ quantitative [QUAN] approach using numeric data within the positivist paradigm. On the other hand, researchers who take the position that the realities are co-constructed between the knower and the known and thus research is subjective typically employ qualitative [QUAL] approach using verbal and textual data with constructivist paradigm. (Teddlie \& Tashakkori, 2009). These different philosophical conflicts between positivism and constructivism have been characterized as a paradigm war (Tashakkori \& Teddlie, 1998).

However, based on the fact that "all methods have their limitations as well as their strength" (Johnson \& Turner, 2003, p. 299), a mixed methods [MM] approach emerged as a "third research movement" (Teddlie \& Tashakkori, 2003, p. ix) under the term of pragmatism for its paradigm (Howe, 1988; Teddlie \& Tashakkori, 2009). Researchers who take the position that there is an external reality which cannot be the absolute truth and that epistemological issues exist often employ MM approach and rely on numeric, verbal, and textual sources of data within a pragmatist paradigm (Teddlie \& Tashakkori, 2003, 2009). To pragmatist researchers, research questions are considered more importantly than either the method they use or the paradigm that underlies the method, which some have referred to as a "dictatorship" of the research question (Tashakkori \& Teddlie, 1998, p. 20).

In order to review and discuss the three (QUAN, QUAL, and MM) methodological approaches in marine educational study, different terms of methodology, methods, and research design need to be clearly defined. Methodology is "the framework that relates to the entire process of research" while methods are "more specific $\cdots$ techniques of data collection and analysis" and research design refers to "the plan of action that links the philosophical assumptions to specific methods" 
(Creswell \& Plano Clark, 2007, p. 4). However, they are all closely connected and collectively shape the kinds of knowledge produced from the research context (Anderson \& Ellenbogen, 2012).

\section{METHODS}

Dr. Rosanne W. Fortner (1991, 2010) compiled up 250 abstracts of research in marine and aquatic education published from 1975 to 2010 and the reports were published through Ohio Sea Grant. From the research papers listed in Fortner' reports, I reviewed journal articles and theses to determine whether (1) the contents obviously dealt with formal and/or informal marine education, (2) the original papers were available in peer reviewed journals or accessible through Pro Quest Direct, and (3) they explicitly represented different designs of QUAN, QUAL, and MM approaches. After reviewing the methodology sections of 98 articles and theses, I identified 11 different research designs (Table 1). Although it is not listed in Fortner's database, I also included one phenomenological case study published by Dohn (2011) because it was recent and comprehensively described the participants' experiences of the phenomenon being studied. Finally, 6 case studies (two for each approach) were included to allow for further discussion and comparative descriptions of designs.

[Table 1] Identified designs of each approach and case selections for further review

\begin{tabular}{c|l|l|c}
\hline & Research Designs & Examples of Studies & Selections for review \\
\hline \hline \multirow{2}{*}{ QUAN } & Survey & Walter \& Lien (1985) & Case 1 \\
\cline { 2 - 4 } & (Quasi)-Experimental & Fortner \& Lahm (1990) & Case 2 \\
\hline \multirow{4}{*}{ QUAL } & Ethnography & Crawford, Kelly, \& Brown (2000) & \\
\cline { 2 - 4 } & Narrative & Ostrenko (2002) & \\
\cline { 2 - 4 } & Grounded theory & Shulte (2009) & Case 1 \\
\cline { 2 - 4 } & Phenomenology & Dohn (2011) & Case 2 \\
\cline { 2 - 4 } & Phenomenography & Ballantyne (2004) 1 \\
\hline \multirow{4}{*}{ MM } & Triangulation & Evans (1997) & Case 2 \\
\cline { 2 - 4 } & Embedded & Greely (2008) & \\
\cline { 2 - 4 } & Explanatory & Kennedy (2010) & Wynveen (2009) \\
\cline { 2 - 4 } & Exploratory & & \\
\hline
\end{tabular}

\section{QUANTITATIVE RESEARCH IN MARINE EDUCATION}

QUAN research employs deductive logic from the general to the particular "to find common patterns in thought and behaviors and to generalize [the findings] broadly"
(Johnson \& Christensen, 2008, p. 53). Since QUAN is typically linked to rigorous scientific methods, researchers collect and analyze numerical data gathered from close-ended questionnaires, checklists, and census records. QUAN research generally adopts survey, correlational, experimental, and quasi-experimental 
design (Teddlie \& Tashakkori, 2009) and is very useful when researchers study large numbers of people and when they want to test hypothesis. Although QUAN study may have higher credibility and generalizability, it is unable to capture the contingencies of the learning process or context such as momentby-moment interaction and complexities of individual or local constituencies' understandings (Anderson \& Ellenbogen, 2012; Shiraev \& Levy, 2006).

In the field of marine education, a considerable number of QUAN studies adopted survey designs (e.g., Fortner \& Mayer, 1991; Kidd \& Kidd, 1998; Snively \& Sheppy, 1991; Steel et al., 2005; Walter \& Lien, 1985; Whitely, 1998) to measure and describe knowledge and attitude levels concerning the oceans, marine animals, and related issues. In order to investigate the effects of a treatment such as newly developed marine educational programs or to identify the relationships among variables experimental or quasi-experimental designs (e.g., Cummins \& Snively, 2000; Fortner \& Lahm, 1990; Souza, 1984) have been adopted in the field. Reviewing the two study cases below, I will discuss how QUAN approach have enabled and constrained our current understandings of students' learning in the field of marine education.

\section{Case 1: National Survey}

Walter and Lien (1985) conducted a national survey to examine Canadian students' ocean literacy focusing on: (1) knowledge about the marine environment and human impact on the oceans; (2) attitudes toward the ocean, marine animals, and marine resource issues; (3) viewpoints in relation to the ocean and its inhabitants; and (4) personal experiences of the ocean. A questionnaire for grade 5 and 9 students was developed by the researchers and was administered by randomly selected classroom teachers across Canada. The numeric data obtained from 3,890 students were compared by variables such as province, grade, and distance from the ocean. Statistical analysis revealed Canadian students' perceptions about the ocean and wildlife. The researchers interpreted the results with tables and graphs.

Given that survey is a design which aims at describing the attitudes, opinions, behaviors, or characteristics of the sample or the entire population (Creswell, 2008) without giving a treatment to the participants (Gall, Gall, \& Borg, 2003), Walter and Lien's study shows a typical survey using close-ended questionnaires that demonstrates overall trends of the phenomenon supported by obvious numeric data. Furthermore, tables and graphs help readers to quickly understand the results. While this design helps researchers and readers to seek answers to "what" questions, its ability to answer 'how' and 'why' questions are limited. For example, Walter and Lien's study cannot answer 'why do Canadian students have mostly spiritual, physical, and aesthetic viewpoints toward marine wildlife rather than recreational, utilitarian, and ecological ones?' Possible answers to this type of question might be better explored through QUAL rather than QUAN data. In sum, survey is a very useful design to gain overall tendencies of a phenomenon and to generalize the results with higher credibility if conducted with randomly 
selected big samples, but hard to gain the details of the phenomenon beyond the numeric data.

\section{Case 2: Quasi-Experimental Study}

Fortner and Lahm (1990) conducted a quasi-experimental study to evaluate effectiveness of the educational program at Old Woman Creek on elementary students' knowledge and attitude change. A total of 204 students of grade 4 and 5 were provided three activities along with three versions of a test to measure their knowledge and attitude change. A pretest was carried out before the first activity which was a half-hour slide presentation supplied by the Creek staff. After the completion of classroom lessons using an information packet given by the Creek staff, an additional test was administered. Then, following a field trip to Old Woman Creek, a posttest was also given to the students. The results of a t-test indicated that the greatest gain in knowledge occurred after the classroom lesson but before their field trip. The t-test also demonstrated that the students' attitudes became significantly more positive between pretest and posttest. Based on these results, the researchers concluded that the Old Woman Creek's program is effective to reach both the school's cognitive goals and the sanctuary's attitudinal goals.

'Experimental' is a very powerful QUAN design if the researcher's goal is to establish cause-and-effect relationships between variables. When experiments are not conducted using random assignment however, they are referred to quasi-experimental design (Gall, Gall, \&
Borg, 2003). Fortner and Lahm's study shows a typical quasi-experimental nonequivalent control group design in which an educational program is used as a treatment for the non-randomly selected samples. The QUAN data analysis drawn from t-test strongly and clearly supports the researchers' conclusion. Hence, the experimental research design can be practical for assessing the effectiveness of ongoing or newly developed marine educational programs. Although this experimental study was suitable to answer the research questions, it did not provide any detailed information regarding the students' experiences. Additional questions such as 'how do the students' field trip experiences contribute to their positive changes in knowledge and attitude?' might be answered through QUAL data gained by interviews or written responses not numeric data.

\section{QUALITATIVE RESEARCH IN MARINE EDUCATION}

QUAL research employs inductive logic from the particular to the general to gain deep insights into a particular phenomenon of interest (Gay, Mills, \& Airasian, 2009). Since QUAL researchers take the position that they construct the meaning of the phenomena, they collect and analyze verbal and textual data gathered from open-ended questionnaire, interviews, observations, documents, and audiovisual materials. QUAL research generally adopts ethnography, phenomenology, grounded theory, historical (narrative) study, and case study for its methodology (Johnson \& Christensen, 2008) 
and is very useful when researchers study a limited number of cases to describe complex phenomena in depth.

Although researchers in the field of marine education have employed various types of QUAL approach such as ethnography (e.g., Crawford, Kelly, \& Brown, 2000), narrative study (e.g., Ostrenko, 2002), and grounded theory (e.g., Shulte, 2009), more QUAL studies have been conducted adopting phenomenology (e.g., Briseno-Garzon, Anderson, \& Anderson, 2007; Dohn, 2011) and phenomenography (Ballantyne, 2004; Marrero \& Moore-Mensah, 2010; Scott, 2007; Snively, 1986) in combination with case study. QUAL approach is very useful to describe the meaning of lived experiences of students and to understand how students conceptualize the marine environment using relatively small number of samples. However, data collection and analysis takes longer time compared to QUAN research. Reviewing two study cases below, I discuss how QUAL approaches have enabled and constrained our current understandings of students' learning in the field of marine education.

\section{Case 1: Phenomenological Case Study}

Dohn (2011) conducted a phenomenological case study to investigate how a field trip to aquarium promotes students' situational interest. A total of 16 students who attended a year 12 biology class participated in this study, and the researcher collected QUAL data from three phases (biology lessons, one entire day aquarium visit, and follow-up activity in the classroom) using observation, video recording, interviews, and student-produced work. These different sources were used to triangulate the results and add credibility to Dohn's interpretation of what students experienced as interesting during the aquarium visit. Data were analyzed using grounded theory (Strauss \& Corbin, 1990). It produced five code domains and the conclusion that the students who participated in the study "experienced situational interest through the museum docent's use of active involvement, novelty and surprise, and social involvement" (pp. 353-354).

Phenomenology is the study of the world or phenomenon when individuals experience it, and subsequently the research focuses on "a comprehensive description of [the participants'] experience of the phenomenon being studied" (Gall, Gall, \& Borg, 2003, p. 482). In this study, the phenomenon being studied is the 'development of students' situational interest' in an aquarium field trip context. Since there was no theory available to explain 'how' the development of situational interest occurs in that context, the researcher collected QUAL data to describe the phenomenon and to generate theory. While phenomenological study is very useful to answer and describe how the participants experience certain phenomena, it may have lower credibility or generalizability than QUAN studies because of relatively small number of participants that were purposefully selected within a specific local context.

\section{Case 2: Phenomenographical Case Study}

Ballantyne (2004) conducted a phenomenographical case study to explore young students' conceptions of and attitudes toward 
marine environment. The researcher conducted focus group interviews with 54 students between 10 and 11 years of age. Students were asked to discuss their general knowledge about the sea, its origins, its inhabitants, and ocean movements. All interviews were audio-recorded and transcribed for analysis. The researcher found that the students held a number of incorrect or partially incorrect conceptions of marine environment. The students' attitudes toward the ocean were mainly egocentric or anthropocentric focused on utilitarian viewpoint.

Phenomenography is "a specialized method for describing the different ways in which people conceptualize the world around them" (Gall, Gall, \& Borg, 2003, p. 483). While individuals grow up, they develop perceptions about their world as a result of both formal and informal learning experiences. Phenomenographical studies are practical for investigating how individuals understand the world, and this study demonstrates well how narrative approaches to data collection and analysis can be used to describe young students' conceptions of the marine environment. Since different people may experience and conceptualize their world in different ways, analysis of QUAL data collected by interviewing each participant can help the researcher understand and represent the complexity and diversity of their various conceptions. Aligned with a constructivist paradigm, all types of conceptions of individuals are meaningful, and thus generalization is not considered. However, like other QUAL studies, phenomenographical research takes longer time to collect and analyze data.

\section{MIXED METHODS RESEARCH IN MARINE EDUCATION}

$\mathrm{MM}$ is "a type of research design in which quantitative and qualitative approaches are used in types of questions, research methods, data collection and analysis procedures, and/or inference" (Teddlie \& Tashakkori, 2003, p. 711). In other words, MM research employs both QUAN and QUAL approaches in an attempt to balance the perceived shortcomings of each approach and consequently to strengthen the study. QUAN data "gives greater breadth" to the study, whereas QUAL gives "greater depth" together it produces the results with "better inferences" (Teddlie \& Tashakkori, 2009, p. 35). MM research is very useful when researchers want to examine and describe specific phenomena in one study. That is, "it enables the researcher to simultaneously ask confirmatory and exploratory questions and therefore verify and generate theory in the same study" (Teddlie \& Tashakkori, 2009, p. 33).

Within the pragmatist paradigm, mixed methodologists provided a justification for combining QUAN and QUAL methods (Teddlie \& Tashakkori, 2009). Based on this justification, MM approach adopts various types of research designs, methodology, and methods according to its research purposes and questions (Newman, Ridenour, Newman, \& DeMarco, 2003; Sandelowski, 2003). Subsequently, infinite numbers of design options might be available in $\mathrm{MM}$ approach (Creswell \& Plano Clark, 2007). According to Teddlie and Tashakkori (2009), however, MM 
research can be grouped into two types in general: parallel and sequential mixed designs. In parallel designs, the QUAN and QUAL strands of the study occur either simultaneously or with some time lapse in sequential designs, the QUAN and QUAL strands of the study occur chronologically. In addition, Creswell and Plano Clark (2007) categorized MM designs into four major types and ten models as shown in Figure 1. However, any design options or modified designs can be used if they best fit to answer the research questions.

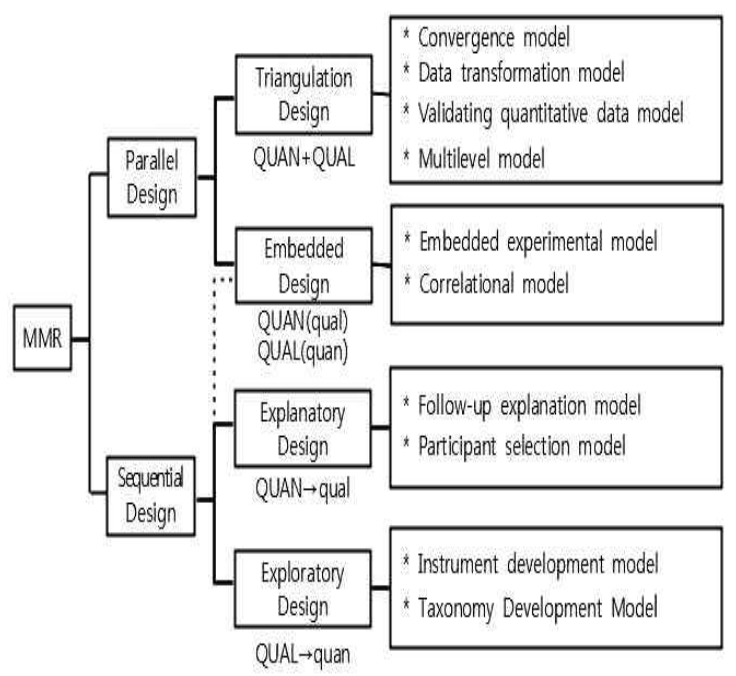

[Fig. 1] Major categories of MM research design (based on Creswell \& Plano Clark, 2007; Teddlie \& Tashakkori, 2009) * a dotted line represents occasional relation

MM research in the field of marine education has employed various designs as following: Triangulation Design when researchers want to compare or validate QUAN results with QUAL findings (e.g., Barney, Mintzes, \& Yen, 2005; Evans, 1997; Sweeney, 2009); Embedded Design when researchers need to include QUAN data within a largely QUAL study or include QUAL data within a QUAN study (e.g., Greely, 2008; Plankis, 2009); Explanatory Design when researchers bring QUAL data as a follow-up to explain QUAN results (e.g., Kennedy, 2010); and Exploratory Design when researcher use the first QUAL study to inform the next QUAN study (e.g., Wynveen, 2009) (Creswell \& Plano Clark, 2007). Each design has been adopted for a particular situation according to a specific purpose. Reviewing two study cases below, I discuss how an MM approach has enabled and constrained our current understandings of students' learning in the field of marine education

\section{Case 1: Triangulation Design}

Evans (1997) conducted a MM study using a typical Triangulation Design in order to evaluate the effectiveness of aquaria (three commercial aquaria located in UK) as centers for marine conservation. The researcher assessed aquaria's conservational roles at multiple levels with different methods: analyzing labels for frequencies of conservation content in exhibit level (QUAL); administering questionnaire in visitor level (QUAN); and conducting interviews in manager level (QUAL). Then those QUAN and QUAL data were merged and triangulated during the interpretation. Textual analysis revealed the aquaria's interpretative materials contained very few messages for conservation. The questionnaires demonstrated no evidence for an increase in understanding of marine conservation. Also, interview results demonstrated 
that managers believed their visitors had a low level of interest in conservation and did not want to gain information for conservation. These synchronized results from different types of data strongly supported the researcher's conclusion.

Rather than collecting and analyzing QUAN or QUAL data from one level, utilizing QUAN and QUAL methods in different levels within a system is called the multilevel model. Similarly, the convergence model (the two sets of results separately collected are converged during the interpretation), data transformation model (one type of data is transformed into the other type), validating quantitative model (open-ended QUAL questions are included into a survey to validate QUAN results) are also commonly employed in a mixed method research as Triangulation Design (Creswell \& Plano Clark, 2007). The argument is that MM approach has stronger evidence for a conclusion owing to the use of additional methods. However, it needs more time and money to collect and analyze both QUAN and QUAL data.

\section{Case 2: Explanatory Design}

Kennedy (2010) conducted an MM study using an Explanatory (or two-phase study) Design in order to explore the impacts of an educational program at Vancouver Aquarium Marine Science Center and to identify the socio-cultural variables that impact students' learning. The researcher developed and administered a questionnaire to assess the participating students' ( $n=129$, grade 11 and 12) environmental attitudes and behaviors in the first stage.
Based on the results of the questionnaire, Kennedy interviewed 14 participants who showed extreme changes in attitude and behavior scores in the second stage. Interviews were carried out two to three weeks after the survey to identify emergent themes and issues based on the results from the questionnaire. Statistical analysis of questionnaire revealed which socio-cultural variables (e.g., gender, parents' birthplace, hobbies, and museum visitation) were related to students' change in attitudes and behaviors after the program. Using emergent key words which impact their perceptional change, interview data helped the researcher to explain how and why students' attitudes and behaviors may have differed depending on their socio-cultural backgrounds

In this Explanatory Design, QUAN component were more emphasized and QUAL data were used as a follow-up to explain QUAN results. Without QUAL component the researcher might get only statistical answers to the questions. However, the interview data offering a deep, insightful reflection of the students' experiences helps the researcher extend understanding about the phenomenon to an individual or local level, which "ascertain the reasons for the results or to find out what is going on" (Teddlie \& Tashakkori, 2003, p. 205).

\section{CONCLUSION}

Researchers utilize diverse methodologies in order to investigate students' learning. Given that each methodology has its strengths and weaknesses (Johnson \& Turner, 2003), understanding these strengths and weaknesses is essential to 
develop best research design and to answer the research questions.

In marine education related researcher, QUAN approach has been employed to identify evidence of learning, significant differences between groups, and significant variables from relatively large samples; QUAL approach has been adopted to understand and describe students' experiences with regard to marine environment and related phenomena, and has often resulted in generating theories or models. While QUAN approach has higher generalizability of the results, QUAL approach has its strong point in helping researchers to deeply understand the situated details of learning process or context at an individual or local level.

MM approach utilizes QUAN and QUAL components together to answer the research questions which dictate the whole process of the study. Compared to QUAN or QUAL, $\mathrm{MM}$ approach is useful to answer different questions in one study. It has more design options and is thought to have better inference quality.

Reviewing the six study cases above demonstrates each methodology's strengths and weakness, contributions and constraints, and relationship with the purposes of the research. It is impossible to judge which one is superior to others, but the decision to choose best research design depends on the research questions and the researcher's paradigm, ontology, and epistemology.

The world we live in is becoming more and more interdisciplinary, complex, and dynamic (Johnson \& Onwuegbuzie, 2004; Pareek \& Rao, 1980). Within these complicated learning environments, it would be hard to understand the inextricable connections between students' learning process, outcome, and influential factors using a single methodology or method. Thus, it is expected to employ diverse methodologies, methods and designs to best understand the intricate marine educational phenomena in Korea.

\section{REFERENCES}

Anderson, D., \& Ellenbogen, K. M. (2012). Learning science in informal contexts: Epistemological perspectives and paradigms. In B. J. Fraser, K. G. Tobin, \& C. J. McRobbie (Eds.), Second international handbook of science education (pp. 1179-1187). New York: Springer.

Ballantyne, R. (2004). Young students' conceptions of the marine environment and their role in the development of aquaria exhibits. The Geojournal, 60, 159 163.

Barney, E. C., Mintzes, J. J., \& Yen, C. F. (2005). Assessing knowledge, attitudes, and behavior toward charismatic megafauna: The case of dolphins. Journal of Environmental Education, 36(5), 41 55.

Briseño-Garzón, A., Anderson, D. \& Anderson, A., (2007). Adult learning experience from an aquarium visit: The role of social interaction in family groups. Curator, 50(3), 299 318.

Cava, F., Schoedinger, S., Strang, C., \& Tddenham, P. (2005). Science content and standards for ocean literacy: A report on ocean literacy. Retrieved August 24, 2010, from http://coexploration.org/oceanliteracy/ documents/OLit2004-05_Final_Report.pdf

Crawford, T., Kelly, G. K., \& Brown, C. (2000). Ways of knowing beyond facts and laws of science: An ethnographic investigation of student engagement in scientific practices. Journal of Research in Science Teaching, 37(3), 237 258.

Creswell, J. W. (2008). Educational research: 
Planning, conducting, and evaluating quantitative and qualitative research (3rd ed.). Upper Saddle River, NJ: Pearson Education.

Creswell, J. W. (2012). Educational research: Planning, conducting, and evaluating quantitative and qualitative research (4th ed.). Boston, MA: Pearson Education.

Creswell, J. W., \& Plano Clark, V. L. (2007). Designing and conducting mixed methods research. Thousand Oaks, CA: Sage.

Cummins, S., \& Snively, G. (2000). The effect of instruction on children's knowledge of marine ecology, attitudes toward the ocean, and stances toward marine resource issues. Canadian Journal of Environmental Education, $5(1), 305 \sim 326$.

Dohn, N. B. (2011). Situational interest of high school students who visit an aquarium. Science Education, 95(2), 337 357.

Evans, K. L. (1997). Aquaria and marine environmental education. Aquarium Sciences and Conservation, 1, 239 250.

Fortner, R. W. (1991). Abstracts of research in marine and aquatic education (1975-1990). Retrieved February 2, 2012, from http://www.oesd.noaa.gov/pubs_reports/EP077_Abstracts_of_Research_in_Marine_and_Aq uatic_Education.pdf

Fortner, R. W. (2010). Abstracts of research in marine and aquatic education (1990-2010). Retrieved February 2, 2012, from http://www.oesd.noaa.gov/outreach/reports/ 2010_Ocean_and_Water_Education_Research_ Abstracts_preface.pdf

Fortner, R. W., \& Lahm, A. C. (1990). Research program outreach into the classroom: An Estuarine Research Reserve program. Journal of Environmental Education, 21(1), 7 12.

Fortner, R. W., \& Mayer, V., J. (1991). Repeated measures of students' marine and Great Lakes awareness. Journal of Environmental Education, 23(1), 30 35.

Gall, M. D., Gall, J. P., \& Borg, W. R. (2003). Educational Research: An introduction (7th ed.). Boston, MA: Allyn and Bacon.
Gay, L. R., Mills, G. E., \& Airasian, P. (2009). Educational research: Competencies for analysis and applications (9th ed.). Upper Saddle River, NJ: Pearson Education Inc.

Greely, T. (2008). Ocean literacy and reasoning about ocean issues: The influence of content, experience and morality. Unpublished doctoral dissertation, University of South Florida.

Howe, K. R. (1988). Against the quantitative -qualitative incompatibility thesis or dogmas die hard. Educational Researcher, 17(8), 10 16.

Johnson, B., \& Christensen, L. (2008). Educational research: Quantitative, qualitative, and mixed approaches. Thousand Oaks, CA: Sage.

Johnson, R. B., \& Onwuegbuzie, A. J. (2004). Mixed methods research: A research paradigm whose time has come. Educational Researcher, 33(7), 14 26.

Johnson, B., \& Turner, L. A. (2003). Data collection strategies in mixed methods research. In A. Tashakkori, \& C. Teddlie (Eds.), Handbook of mixed methods in social and behavioral research (pp. 297 320). Thousand Oaks, CA: Sage.

Kennedy, J. E. (2010). Experiential environmental education: Looking at the socio-cultural variables that affect attitudes and behaviours following a marine conservation program. Unpublished master's thesis, University of British Columbia, Vancouver, British Columbia, Canada.

Kidd, A. H., \& Kidd, R. M. (1998). General attitudes toward and knowledge about the importance of ocean life. Psychological Reports, 82, 323 329.

Marrero, M. E., \& Moore-Mensah, F. M. (2010). Socioscientific decision making and the ocean: A case study of 7 th grade life science students. Journal of Electronic Science Education, 14(1), 1 27, Retrieved December 28, 2011, from http://ejse.southwestern.edu/ article/download/7356/5615

Maxwell, J. A. (2005). Qualitative research design: An interactive approach. Thousand Oaks, CA: Sage. 
Mayer, V. J., \& Fortner, R. W. (1985). Marine and aquatic education. In J. Lien \& $\mathrm{R}$. Graham (Eds.), Marine Parks and Conservation: Challenge and Promise (pp. 158 166). St. John's, NFLD: National and Provincial Parks Association of Canada.

Newman, I., Ridenour. C., Newman, C., \& De Marco, G. (2003). Typology of purpose: A tool for thinking about research questions, designs, and mixed methods. In A. Tashkkori \& C. Teddlie (Eds.), Handbook of mixed methods in social and behavioral research (pp. 167 188). Thousand Oaks, CA: Sage.

Ostrenko, M. Z. (2002). Learning conversations at a marine science center. Unpublished doctoral dissertation, University of South Florida.

Pareek, U., \& Rao, T.V. (1980). Cross-cultural surveys and interviewing. In H. C. Triandis, \& J. W. Berry (Eds.), Handbook of cross-cultural psychology (Vol. 2, pp. 127 179). Boston, MA: Allyn \& Bacon.

Plankis, B. J. (2009). Examining the effects of technology-infused issue investigations on high school students' environmental and ocean literacies, Unpublished doctoral dissertation, University of Houston. Texas.

Sandelowski, M. (2003). Tables or tableaux? The challenges of writing and reading mixed methods studies. In A. Tashakkori, \& C. Teddlie (Eds.), Handbook of mixed methods in social and behavioral research (pp. 321 350). Thousand Oaks, CA: Sage.

Scott, S. A. (2007). Children's environmental knowing: A case study of children's experiences during an environmental education program. Unpublished doctoral dissertation, University of British Columbia. Vancouver, British Columbia, Canada.

Shiraev, E., \& Levy, D. (2006). Cross-cultural psychology: Critical thinking and contemporary applications (3rd ed.). Boston, MA: Pearson Education.

Shulte, P. J. (2009). A model marine-science curriculum for fourth-grade pupils in
Florida. Unpublished doctoral dissertation, Union Institute and University, Florida.

Snively, G. (1986). Sea of images: A study of relationships amongst children's beliefs, orientations, and science instruction. Unpublished doctoral dissertation, University of British Columbia, Vancouver, British Columbia, Canada.

Snively, G., \& Sheppy, J. (1991). The kids are saying: Save our endangered oceans. Current, 10(2), 14 20.

Souza, R. (1984). Marine science: Knowledge and attitudes of high school students. Unpublished doctoral dissertation, Boston College, Massachusetts.

Steel, B. S., Smith, C., Opsommer, L., Curiel, S., \& Wagner-Steel,R. (2005). Public ocean literacy in the United States. Ocean \& Coastal Management 48, 97 114.

Strauss, A., \& Corbin, J. (1990). Basics of qualitative research: Grounded theory procedures and techniques. Newbury Park, CA: Sage.

Sweeney, D. L. (2009). Learning in human -dolphin interactions at zoological facilities. Unpublished doctoral dissertation, University of California, San Diego, California.

Tashakkori, A., \& Teddlie, C. (1998). Mixed methodology: Combining the qualitative and quantitative approaches. Thousand Oaks, CA: Sage.

Teddlie, C., \& Tashakkori, A. (2003). Major issues and controversies in the use of mixed methods in the social and behavioral sciences. In A. Tashakkori, \& C. Teddlie (Eds.), Handbook of mixed methods in social and behavioral research (pp. 3 50). Thousand Oaks, CA: Sage.

Teddlie, C., \& Tashakkori, A. (2009). Foundations of mixed methods research: Integrating quantitative and qualitative approaches in the social and behavioral sciences. Thousand Oaks, CA: Sage.

Walter, H., \& Lien, J. (1985). Attitudes of Canadian students and teachers toward the marine environment and marine education. In J. Lien, \& R. Graham (Eds.), Marine 
parks and conservation challenge and promise (Vol. 1, pp. 187 204). National and Provincial Parks Association of Canada.

Whitley, L. N. (1998). Cultural diversity and attitudes toward marine wildlife. Unpublished master's thesis, University of Southern California.

Wynveen, C. J. (2009). Place meaning and attitudes toward impacts on marine environments.
Unpublished doctoral dissertation, Texas A\&M University.

- 논문접수일 : 2012년 10월 25일

- 심사완료일 : 1차 - 2012년 11월 10일

2차 - 2012년 11월 18일

- 게재확정일 : 2012년 11월 21일 